\title{
CYTOTOGENETIC STUDIES ON THE EFFECTS OF ACUTE EXPOSURE TO LANNATE ON MICE
}

\author{
Hemeda, SH. A. *; Abou-Ismail, U. A.** and El-henawy, D. M.** \\ 'Department of Anlmal Husbandry, Faculty o[ Veterinary Medlclne. Alexandna Univerglty. "* \\ Department of AnImal Husbandry, Faculty of Velennary Mediclne, \\ Mansoura University. Mansoura, Egvpt.
}

\begin{abstract}
Although carbanate pesticides are widely used, research has shown that they have various side effects. The aim of this study was therefore to investigate the cytogenetic effects of Lannate on mice. Another aim of the study was to investigate the protective effect of olive oil agninst the cytogenctic effects of Lannate. 36 Sulss albino mice were exposed to various concentrations of Lannate, Lannate and olive of or were kept as controls. Antmals were sampled at two different tines (24 and 48 hrs). Lannate increased the number of structural and numerical chromosomal aberrattons per cell. On contrary. Lannate pradired no eflects on the rate of cell diviston (mitotuc index) at either 24 or 48 hrs. Moreover, the use of olwe oil gave promising results against Lannate taxiclty as it significantly decreased the frequency of chromosorial aberrations.
\end{abstract}

\section{INTRODUCTION}

Carbanates are a member of large group of synthetir pesticldes that have bcen developed and used on a large scale over the last 50 years. Several rcports showed that some of these carbamates have many side effeets including genetie damage and mutagenic cffects (Moucshen- Dahmen et al., 1984). Methomyl is one of the most toxic methyl carbamate pestjcldes. It Is a derlvatlve of carbamic acid that has been widely marketed since 1967 under the trade name (Lannate). Despitc its wide application. Lannate Is classifled by the Environmental Protection Agency (EPA) as a restricted usc pesticlde (RUP) or a Highly Hazar dardous class (Farre et al., 2002). The gcnotoxucity of Lannate has been deseribed by several studies. Some studies showed that Lannate has genotoxdc effccts ineluding chro. mosornal aberration and sister chromatld exchanges (Hemvathy and Krishamurthy 1987; Guintana et al., 1993; Amer et al., 1996 and Blevins et al., 1997). Lannate has bcen shown to have mutagenic action (Dean Blewns et al., 1977; Hayes, 1982; Waters et al., 1982 and Wang et al., 1998). Lannate has also becn demonstrated to have inhibitory efrecis demonstrated by law mitotic index (Quintana et al., 1993). Gcnotoxic activity of Lannate may be due to the Inhibttion of some essentral enxymes leading to DNA damage (Rannug and Rannug, 1984), alkalyting acUvity (guintana et al., 1993) and formation of reactive oxygen species. On Other hand. 
other studies showed that Lannate has no genotoxic or mutagenlc action (Wojclechowsk et al., 1982 and Farrow et al., 1984). Recent attention has focused on a number of non vilamin antloxddant such as olive oll. Olive oll is a prime eomponent of the Mediterranean diet. It has a protectlve funetion and many beneficlal cffects including the proteetuon against ulcers, gastritls and eolon eancer (Bartoll et al., 2000). These beneffcial effects: of ollve ofl are thought to be related to its ants. oxidant and cytopotectlve effects (Pompella, 1997).

The present study was therefore carted out to investigate the cytogenetic effects of th: acute exposure to Lannate on mice and the possible protective effects of ollve oil agalnst Lannate toxdcity.

\section{MATERIALS AND METHODS}

Methomyl was obtained from DuPont $\mathrm{CO}$. U.S.A. as a commerclal preparation of "Lannate 90 SP". Ollve oll was oblained from Rafael Salgado- Spain (RS).

36 Swiss alblno mlce (Mus musculus) were obtained from experimental animal farm in Helwan and were used in this study. They were 8-10 wcak old and weighted 20-25g at the beginning of thc experiment. Pelleted ration and water were offered ad-llbitum. Mice were divided into six experimental groups of stx animals. Lannate was injected intraperitoneally simultaneously with a single dose of ollve oll by gavage as shown in table (1).

All animals were injected Intaperitoneally with $1 \mathrm{mg} / 1 \mathrm{ml}$ of aquas solution of colchlcines two hours before the time of the sacriflce
(Aboul- Ela, 2002). Bone marrow preparatuons for the analysis of chromosome aberrations In metaphase cell were oblained by technlques of Girl et al.. (1986). One hundred metaphases per anlmal were analyzed in order to determine the frequencies of ehromosomal aberration. The mitotic index in 3000 cells per group was also analyzed. Statustieal analysis was done using one way analysts of varlance by SPSS. Mitotle index was analyzed by Chl square analysis by $M$ - state.

\section{Chromosomal aberrations:
1. 1. Twenty four hours (24 hre) treat- ment:

Means \pm SE of total aberrant metaphase cells in the control (without any treatment and olive oll group) and treated groups (1/10 $\mathrm{LD}_{50}, 1 / 10 \mathrm{LD}_{50}$ of Lannate \pm ollve oll. $1 / 5$ $L D_{50}$ and $1 / 5 L D_{50}$ of Lannate \pm ollve oll) are present in table (2). The results showed that thicrc was no slgniflcant difference between the two control groups $(12.00 \pm 1.53$ and $11.67 \pm 1.76$ respectively). There was however a signiffcant dyfference between the treated and the control groups. On the other hand. there was no signilicant difference between the group treated with $1 / 10 \mathrm{LD}_{50}$ of Lannate \pm ollve oll and $1 / 5 L_{50}$ of Lannate \pm ollve oll (30.33 \pm 0.33 and $31.33 \pm 0.88$ respectlvely) whilc there was a signiffcant difference between the group treated with $1 / 10 \mathrm{LD}_{50}$ of Lannate and $1 / 10 \mathrm{LD}_{50}$ of Lannate and olive oll $(32.67 \pm 0.33$ and $30.33 \pm 0.33$ respectlvely). Moreover, there was a slgniflcant difference between the group treated with $1 / 5$ $\mathrm{LD}_{50}$ of Lannate and $1 / 5 \mathrm{LD}_{50}$ of Lannate \pm olive oll $(35.00 \pm 1.45$ and $31.33 \pm 0.88$ respectively). The different types of aberrations 
of treated and control yroups are presented in table (3) and figures (2-12).

\subsection{Forty elght hours (48 hrs) treat- ment:}

Means \pm SE of total aberrant cells of the two control groups and the treated groups for 48 hrs are presented in table (4). The result showed that therc was a signifleant difference between the two control groups at one side and the treated groups at the other side. However, no signiflcant difference was observed between two control groups. There was also no significant difference between groups treated with $1 / 10 \mathrm{LD}_{50}$ of Lannate \pm ollve oll and groups treated with $1 / 5 L_{50}$ of Lannate \pm olive oll $132.67 \pm 1.45$ and $33.33 \pm 0.33$ respectively). However, thcre was a signiflcant difference between the groups treated with $1 /$ $10 L D_{50}$ of Lannate, $: / 10 L D_{50}$ of Lannate \pm olive oll $(32.67 \pm 1.45$ and $29.33 \pm 0.67 \mathrm{re}$ spectuvelyl. and between groups treated with 1/5 LD 50 of Lannatc. The 1/5 LD 50 of Lannate showed the highest mean for aberrant cells (34.67 \pm 0.88). The data listed in table (5) Illustrate the most prominent type of chromosomal aberratlans observed.

\section{Mitotle Inder:}

I. 1. Twonty four hours (24 hre) treat. mont:

Chi square values of the two control groups and treated groups showed that there were no slgniffcant differences between the control and the treated groups (table 6 and 7 ).

\subsection{Forty elght hours ( $48 \mathrm{hro}$ ) treat- ment:}

Ch1 square analysis showed that there were no signiflcant differences between the eontrol and the treated groups. These results are presented in table (8 and 9 ).

\section{DISCUSSION}

The results of the acute exposure to Lannate Indleated that the acute treatment with Lannate for 24 and 48 hrs caused a signiflcant tncrease in the aberrations of chromo. somes. The rcsults also lllustrated that ollve oll showed a protectivc effcet and decreased the occurnence of chromosomal abcrration. These findings agree with those of Allen et a.. (1982) regarding ethyl carbamate and related metabolite vinyl carbanate both in Hvo and in vitro. Allen et al., (1982) found that ethyl carbamate caused an inerease in single chromatid exchanges (SCEs) In vivo only. On the other hand, vinyl carbarnate Induced SCEs in vivo and in vito. Similar results were obtained by DeBuyst and Vanlarobeke. (1982) who showed that Lannate induced sister chromatid exchanges in human lymphocytes cultures. Also wHo, (1986) obtained results agree with the present results on Chinese hamster ovary cells treated with benamyl (a carbamate pesticide) which induced sister chromatid exchangeo and chromosomal abnomalities. The results of Hepevathy and Rriohnamurthy, (1887) who found that Lannate 20 caused chromosomal perrations on germ cells of mice at 24 hrs agree also with Endings of the present study. The results of Boderpalm-Bernde and Onflet, (1988) are also in accordance with the reported results on earbaryl in mammalian cells. The authors found that carbaryl induced chromosomal aberrations malnly aneuploidy through the disturbance of splndle flbre. Ashry. (1980) studled the acute genotoxic effect of Temik and Carboluran on bone marrow of rats and found 
that Temik and Carbofuran fnduced numertcal and structural chromosomal aberratons such as polyploidy, ring chromosome. end to end dissotadon. stlckiness, hypoploldy and centromeric attenuatlon. The resyths are also in accordance with the Anding of Oupintann et al. (1893) who reported that Lapsate iruluced chromatld aberration frequencles, (Iragment and bridges) at four hrs in Vịta. Faba.

:14:?: .

I-The present results also agree with the re. sult of Arner et al., (1996) who reported thats. Lanpate caused madmum chromosomal ab. erration. at 24:hra after injectlon intraperitonefly $(y, d n$ mice and with those of Kevekorden et. (1896) who notleed that aldicarb (car: bawate i pesticldes) Induced increases in the frequangy of slster chromatid .exchanges in cultuge human lymphocytes at $24 \mathrm{hrs}$. The result of this work are alsq in an agreement within(hase af Topakate et al., (1996) who found, that marshal (carbanate pesucldes) Irduced chromosomal abnormalttles in bone marrow cells of rats. On contrary. these, rir sults; disagree wth those obtained by waters; et, at (lig82) who reponted that Lannate was,

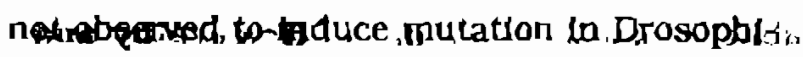
la melanghater. This disoreparay, betwerzis

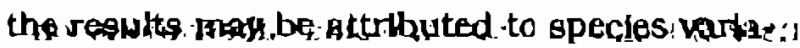

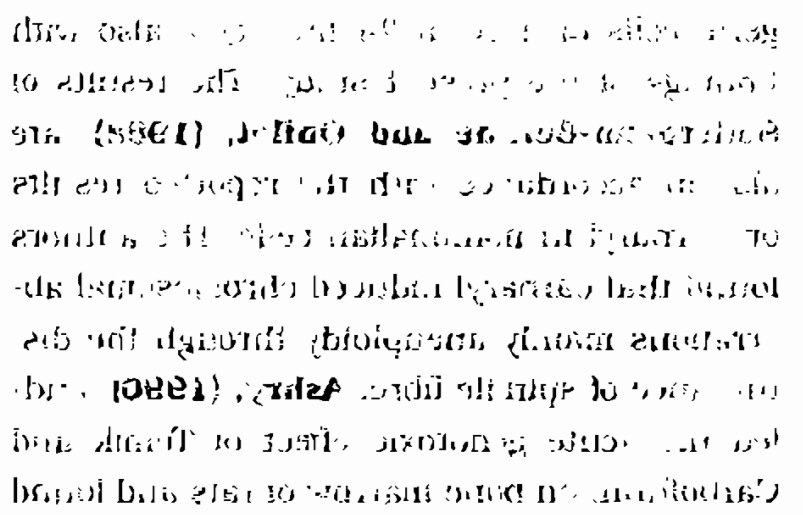

Lun and cufferences in experimental design. Manna et al., (2002), reported that extra virgin ollve oll had a protective effect against the cytotopdc effects of reactive axygen species in human erythrocytes and oxddatlve damages. Simllarly, Evangellata ot al.. (2004) showed that oljue and extra vigln olve decreased the chromosomal, aberrations and abnormal met : aphases, inducerd by acute exposure' 10 ant: negplastlc drug cisplatin.

r-Fiom the provious results it could be reported that Lannate, and/or olive oll had no effects on mitotic index th the acute exposure treatment. These results agree. with thase of Farrow ot al.; (1084) who found that Lannate had no effects on milotic Index lo rats exposed to 2. 6, $20 \mathrm{mg} / \mathrm{kg}$ B.wt of Lannate lor 6. 24 and: 48 hrs: On contrary; these results disagree with the results of Aolurg. (1900) who reported, that Temuk and Carbofuran decreased the percentage of cell under going $\mathrm{ml}-$ tosis and chrt et al., (1993) wboishowed that carbosulian induced a celtitysle delay.. StmL - : larty, gadrone et al., (1909) (rectrded that ,

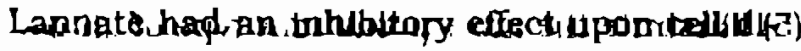

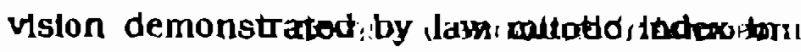
Vtcla Faba root at $4 \mathrm{hrs}$. These differences between the resulty may be: to difertentes

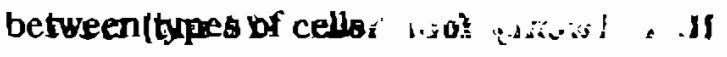

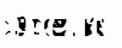

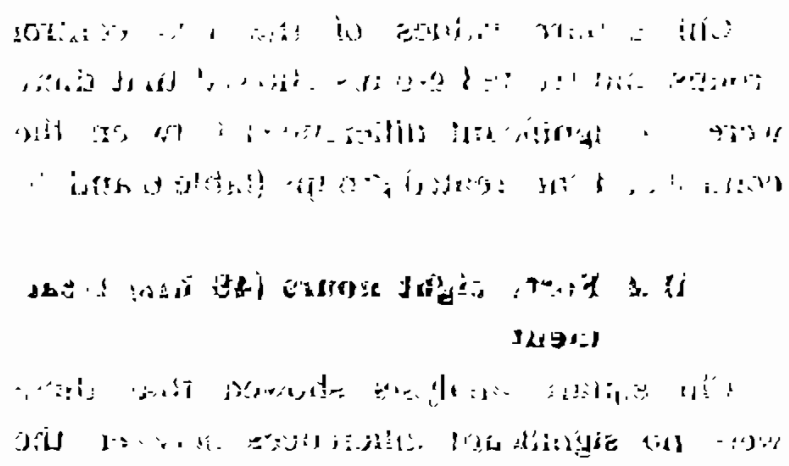


Table (1): The experimental design of the acule exposure to Lannate (24 and 48h).

\begin{tabular}{|c|c|c|c|c|}
\hline Group & Treatment & Dose & $\begin{array}{c}\text { Time of } \\
\text { exposure/hours }\end{array}$ & $\begin{array}{l}\text { No. of } \\
\text { animals }\end{array}$ \\
\hline 1 & Control & - & 24 and 48 & 6 \\
\hline 2 & Olive oil & $10 \mathrm{mg} / \mathrm{kg} \mathrm{B} . \mathrm{wt}$ & 24 and 48 & 6 \\
\hline 3 & Lannate & $1 / 10 \mathrm{LD}_{30}$ & 24 and 48 & 6 \\
\hline 4 & Lannate and olive oil & $\begin{array}{l}1 / 10 \mathrm{LD}_{30} \text { and } \\
10 \mathrm{ml} / \mathrm{kg} . \mathrm{wt}\end{array}$ & 24 and 48 & 6 \\
\hline 5 & Lannate & $1 / 5 \mathrm{LD}_{50}$ & 24 and 48 & 6 \\
\hline 6 & Lannate and olive oil & $\begin{array}{l}1 / 5 \mathrm{LD} \text { so and } \\
10 \mathrm{~m} / \mathrm{kg} . \mathrm{B} . \mathrm{wt} .\end{array}$ & 24 and 48 & 6 \\
\hline
\end{tabular}

Table (2 ): Means of aberrant cells in animals recelved Lannase andor alive oil after 24 hrs.

\begin{tabular}{|c|c|c|c|}
\hline Group & $\begin{array}{c}\text { No. of } \\
\text { animals/group }\end{array}$ & $\begin{array}{c}\text { No. of examined } \\
\text { cells/animal }\end{array}$ & $\begin{array}{c}\text { Aberrant cells } \\
\text { (means } \pm \text { SE) }\end{array}$ \\
\hline Control & 3 & 50 & $12.00 \pm 1.53^{\mathrm{d}}$ \\
\hline Olive oil & 3 & 50 & $11.67 \pm 1.76^{\mathrm{d}}$ \\
\hline Lannate $1 / 10 \mathrm{LD}_{\mathrm{g} 0}$ & 3 & 50 & $32.67 \pm 0.33^{6}$ \\
\hline Lannate $1 / 10 \mathrm{LD}_{30}+$ olive oil & 3 & $5 \overline{0}$ & $30.33 \pm 0.33^{c}$ \\
\hline Lannate $1 / 5 \mathrm{LD}_{\mathbf{s}}$ & 3 & 50 & $35.33 \pm 1.45^{\mathrm{g}}$ \\
\hline Lannate $1 / 5 \mathrm{LD}_{s 0^{+}}$olive oil & 3 & 50 & $31.33 \pm 0.88^{c}$ \\
\hline
\end{tabular}

Means having different letrers are significantly different at the level of $P<0.05$. 


\begin{tabular}{|c|c|c|c|c|c|c|c|c|c|c|c|c|}
\hline \multirow{2}{*}{$G_{n=m}$} & \multicolumn{12}{|c|}{ 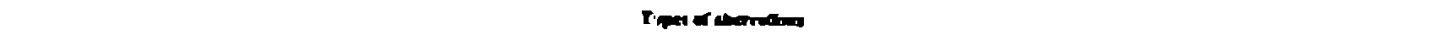 } \\
\hline & Mathy & 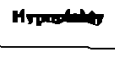 & Gm & Dranam & Cremalle & $\begin{array}{c}\text { Corminum } \\
\text { brite }\end{array}$ & Cming & 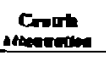 & 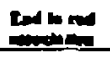 & 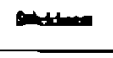 & 15int & Qromomik \\
\hline Comito & $0.00+0.011$ & $0.00=000$ & $1.00=0.40^{\prime \prime}$ & " & 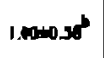 & $0.14+0.33^{b}$ & $0.33 \div 0.13^{4}$ & $4.87 \pm 1.04^{d}$ & $200+1.5)^{2}$ & $2340 . \mathrm{x}^{\mathrm{C}}$ & $0.67 \pm 0.6 T^{\circ}$ & 0.000 .006 \\
\hline and & a.symasst & $2.3=0.0$ & $0.00=0.006$ & (.Jנ二n & $0.004 \pi 0^{6}$ & $1.1340 .10^{\circ}$ & $133 \mathrm{Amab}$ & אי It & $4.00+1.13^{\circ}$ & $13+20^{6}$ & 0.0000 .000 & $0.0010 .00^{\circ}$ \\
\hline Lento & $1000 a^{\circ}$ & J.J1ant & $\cot 0.50^{\circ}$ & $21 \div 0 v^{b}$ & $6.000 .94^{2}$ & $3.01 \div 0.11^{6}$ & $2,5 ! 403]^{b}$ & garasest & $4.00 \pm 0.11^{b}$ & 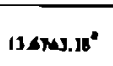 & $2.67+0.5 \mathrm{~J}^{\circ}$ & $1000.30^{\circ}$ \\
\hline $\begin{array}{l}\text { Lannake } \\
\text { viotentat } \\
\text { and }\end{array}$ & $1.00 \times 000$ & $401+1,15^{\circ}$ & $6.00 \pm 0.5 x^{\circ}$ & 23100.00 & " & "1.1.1. & 2.1500000 & $\log ^{2}$ & a $A 7 \infty 4^{b}$ & $6.210 \mathrm{~m}^{\mathrm{b}}$ & "ק. & $0 \operatorname{sen} 10^{\circ}$ \\
\hline 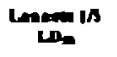 & $100 \times 1 .\left(y^{2}\right.$ & $100 \times 0.00$ & $2.0000000^{b}$ & $6.00 \times 1.19^{\circ}$ & $200 \div 0.006$ & $6.00 \times 1, s^{1}$ & 65i & 11.00.st" & $14.67 \pm 1 \sigma^{\prime}$ & $0.00=1.13^{6}$ & OJW20" & $2,0 \times+1,0^{2}$ \\
\hline 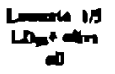 & $0.140 .53^{*}$ & J.J4 $0.60^{\circ}$ & $3.00+115^{\circ}$ & $60001.19^{1}$ & $900+1.15^{6}$ & $6.00+1.11^{\circ}$ & $6.0041,15^{1}$ & $7.000 .010^{*}$ & $2.0=0.10^{\circ}$ & $11 \sin$ & 2670.04 & $0.00+0.010$ \\
\hline
\end{tabular}

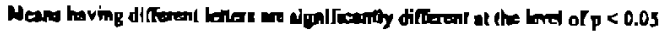

Table (4): Means of aberrant cells in animals received Lannate and/or olive oil after 48 hrs.

\begin{tabular}{|c|c|c|c|}
\hline Group & $\begin{array}{c}\text { No. of } \\
\text { animals/group }\end{array}$ & $\begin{array}{c}\text { No. of examined } \\
\text { cells/animal }\end{array}$ & $\begin{array}{c}\text { Aberrant cells } \\
\text { (means } \pm \text { SE) }\end{array}$ \\
\hline Control & 3 & 50 & $12.00 \pm 0.58^{\mathrm{d}}$ \\
\hline Olive oil & 3 & 50 & $14.33 \pm 0.67^{\mathrm{d}}$ \\
\hline $1 / 10 \mathrm{LD}_{50}$ of Lannate & 3 & 50 & $32.67 \pm 1.45^{\mathrm{b}}$ \\
\hline $\begin{array}{c}\text { 1/10 LD } D_{50} \text { of Lannate }+ \\
\text { olive oil }\end{array}$ & 3 & 50 & $29.33 \pm 0.67^{c}$ \\
\hline $1 / 5 \mathrm{LD}_{50}$ of Lannate & 3 & 50 & $34.67 \pm 0.88^{\mathrm{a}}$ \\
\hline $\begin{array}{l}1 / 5 \mathrm{LD}_{s v} \text { of Lannatet } \\
\text { olive oil }\end{array}$ & 3 & so & $33.33 \pm 0.33^{\mathrm{b}}$ \\
\hline
\end{tabular}

Means having different letters are significantly different al the level of $\mathbf{P}<0.05$. 
Hemeda, SH. A.; et al...

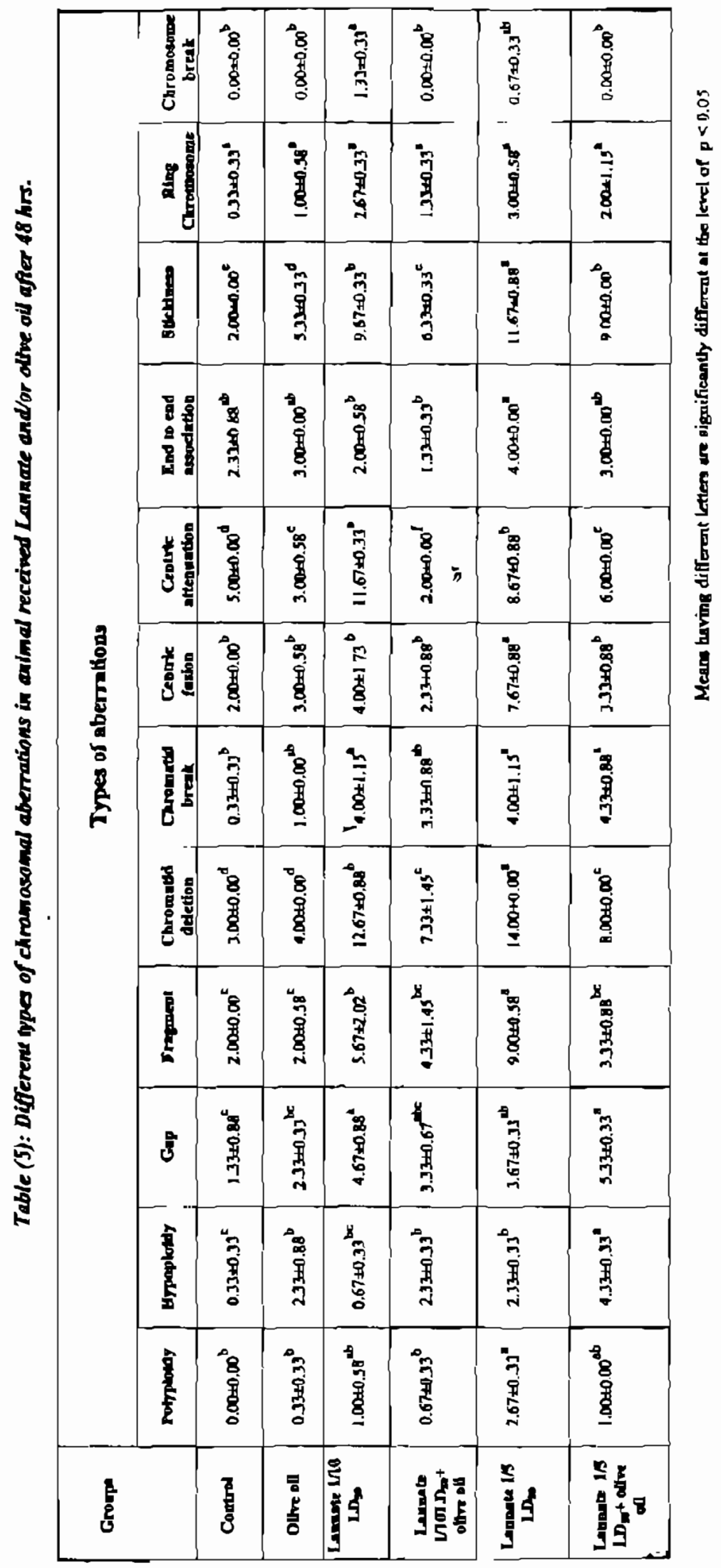

Mansoura, Vet. Med. J.

Vol. XI, No. 2, 2009 
Table (6): Mitotic index (M.I) in animals received Lannate and /or olive oil after $24 \mathrm{hrs.}$

\begin{tabular}{|c|c|c|c|c|}
\hline Group & $\begin{array}{c}\text { Total No. of } \\
\text { exgmined cells }\end{array}$ & $\begin{array}{c}\text { No. of } \\
\text { divided cells }\end{array}$ & $\begin{array}{l}\text { No, of non } \\
\text { divided cells }\end{array}$ & M.I \\
\hline Control & 3000 & 130 & 2870 & 4.33 \\
\hline Olive oil & 3000 & 134 & 2866 & 4.47 \\
\hline Lannate $1 / 10 \mathrm{LD}_{30}$ & 3000 & 124 & 2876 & 4.13 \\
\hline $\begin{array}{c}\text { Lannate } 1 / 10 \mathrm{LD}_{50}+ \\
\text { olivc oil }\end{array}$ & 3000 & 126 & 2874 & 4.20 \\
\hline Lannate $1 / 5 \mathrm{LD}_{50}$ & 3000 & 115 & 2885 & 3.83 \\
\hline $\begin{array}{c}\text { Lannate } 1 / 5 \mathrm{LD}_{50}+ \\
\text { olive oil }\end{array}$ & 3000 & $1 \overline{25}$ & $287 \overline{5}$ & 4.17 \\
\hline
\end{tabular}

Table (7): Chi square values of mitotic index in animals received Lannate and /or olive oil afler 24 hrs.

\begin{tabular}{|c|c|c|c|c|c|c|}
\hline \multirow[b]{2}{*}{ Group } & \multicolumn{6}{|c|}{ Chi square value } \\
\hline & Control & Olive oil & $\begin{array}{l}1 / 10 \mathrm{LD}_{30} \\
\text { Of Lannate }\end{array}$ & $\begin{array}{l}\text { 1/10 LD } \\
+ \text { olive oil }\end{array}$ & $\begin{array}{l}\text { I/5 LD } \\
\text { Of Lannate }\end{array}$ & $\begin{array}{r}1 / 5 L_{50} \\
+ \text { olive oil }\end{array}$ \\
\hline \multicolumn{7}{|l|}{ Control } \\
\hline Olive oil & 0.0356 & & & & & \\
\hline $\begin{array}{l}1 / 10 \mathrm{LD}_{x_{0}} \\
\text { Of Lannate }\end{array}$ & 0.103 & 0.330 & & & & \\
\hline $\begin{array}{l}\text { 1/10 LD } \\
+ \text { olive oil }\end{array}$ & 0.037 & 0.196 & 0.0042 & & & \\
\hline $\begin{array}{l}\text { 1/S LD } 50 \text { of } \\
\text { Lannate }\end{array}$ & 0.834 & 1.360 & 0.278 & 0.334 & & \\
\hline $\begin{array}{l}1 / 5 \mathrm{LD}_{50} \\
+ \text { olive oil }\end{array}$ & 0.0655 & 0.258 & 0.0100 & 0.000 & $0 . \overline{351}$ & \\
\hline
\end{tabular}


Table (8): Mitotic index in animals received Lannate and lor olive oil after 48 hrs.

\begin{tabular}{|c|c|c|c|c|}
\hline Group & $\begin{array}{l}\text { Total No. of } \\
\text { examined cells }\end{array}$ & $\begin{array}{l}\text { No. of divided } \\
\text { cells }\end{array}$ & $\begin{array}{l}\text { No. of non } \\
\text { divided cells }\end{array}$ & M.I \\
\hline Control & 3000 & 132 & 2868 & 4.40 \\
\hline Olive oil & 3000 & 128 & 2872 & 4.27 \\
\hline I/I0 LD $\mathrm{LD}_{50}$ of Lannate & 3000 & 116 & 2884 & 3.87 \\
\hline $\begin{array}{l}1 / 10 \text { LD } \\
\text { olive of Lannate }\end{array}$ & 3000 & 125 & 2875 & 4.17 \\
\hline 1/5 LD 50 of Lannate & 3000 & 111 & 2889 & 3.70 \\
\hline $\begin{array}{l}\text { I/S LDso of Lannatet } \\
\text { olive oil }\end{array}$ & 3000 & 128 & 2872 & 4.27 \\
\hline
\end{tabular}

Table (9): Chi square values of mitotic index in animals received Lannate and /or olive oil afler 48 hrs.

\begin{tabular}{|c|c|c|c|c|c|c|}
\hline \multirow[b]{2}{*}{ Group } & \multicolumn{6}{|c|}{ Chi square value } \\
\hline & Control & Olive oil & $\begin{array}{c}1 / 10 \text { LD } \\
\text { of } \\
\text { Lannate }\end{array}$ & $\begin{array}{c}1 / 10 \mathrm{LD}_{50} \\
+ \\
\text { olive oil }\end{array}$ & $\begin{array}{c}1 / 5 \mathrm{LD}_{50} \\
\text { of } \\
\text { Lannate }\end{array}$ & $\begin{array}{c}1 / 5 \mathrm{LD}_{50} \\
+ \\
\text { olive oil }\end{array}$ \\
\hline \multicolumn{7}{|l|}{ Control } \\
\hline Olive oil & 0.036 & & & & & \\
\hline $\begin{array}{l}1 / 10 \mathrm{LD}_{30} \\
\text { of Lannate }\end{array}$ & 0.950 & 0.516 & & & & \\
\hline $\begin{array}{l}1 / 10 \mathrm{LD}_{50} \\
+ \text { olive oil }\end{array}$ & 0.146 & 0.0165 & 0.276 & & & \\
\hline $\begin{array}{c}1 / 5 L D_{50} \\
\text { Of Lannate }\end{array}$ & 1.720 & 1.120 & 0.073 & 0.745 & & \\
\hline $\begin{array}{l}1 / 5 \text { LD } \\
+ \text { olive oil }\end{array}$ & 0.036 & 0.000 & 0.516 & 0.0165 & 1.120 & \\
\hline
\end{tabular}




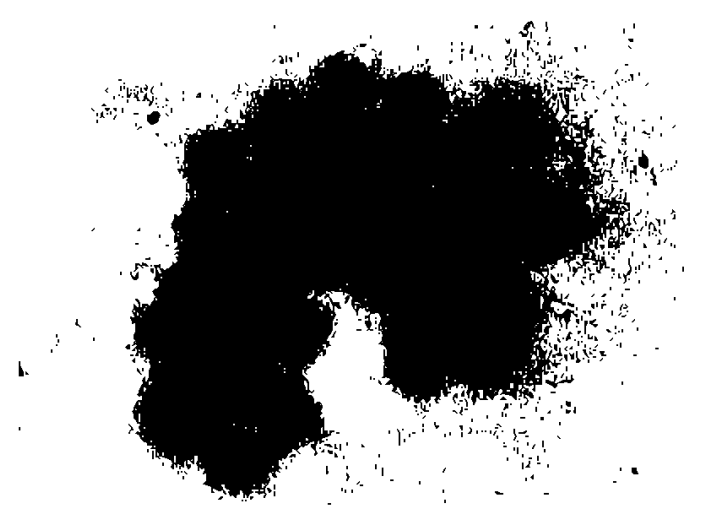

Fig (1): Normal metaphases chromosomes of mice bone marrow cells.

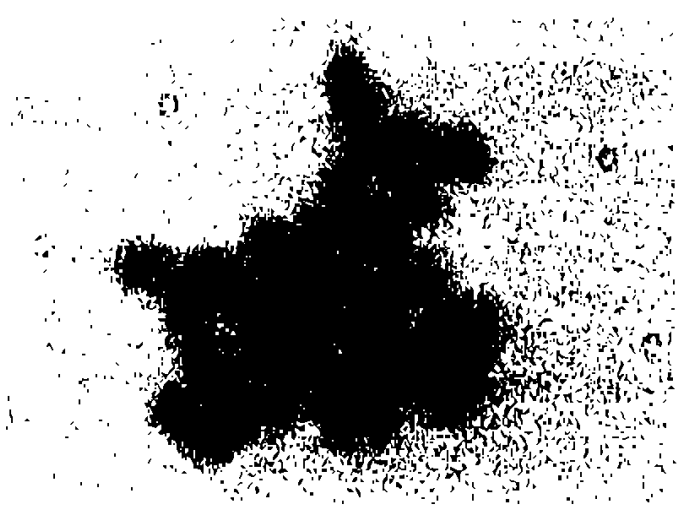

Fig (3): Melaphase chromosomes of mice bone marrow cells efter Lannate treatmenl showing hypoploidy.

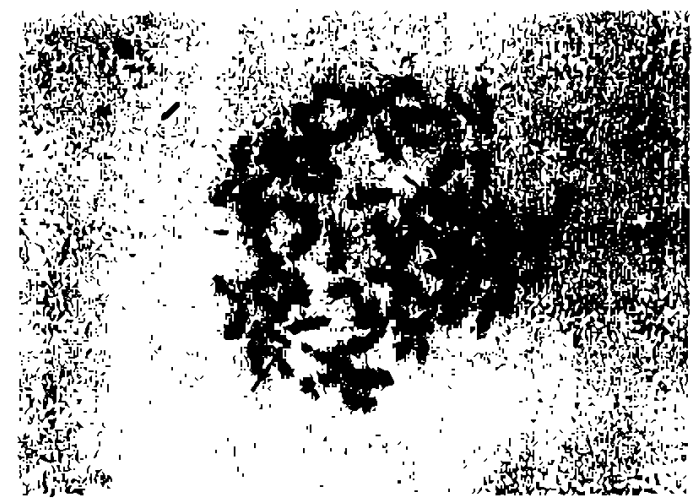

Flg (5): Metaphase chromosomes of mice bone marrow cells after Lannate treatment showing chromosome fragment.

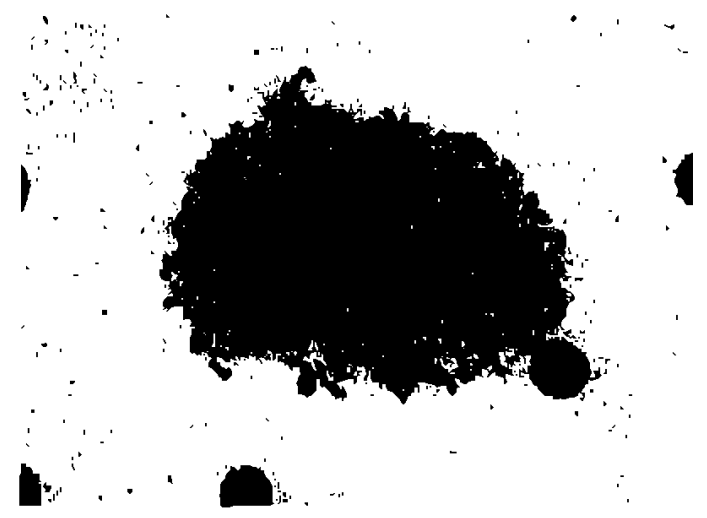

Fig (2): Metaphase chromosomes of mice bone marrow cells after Larnate treatment showing polyploidy.

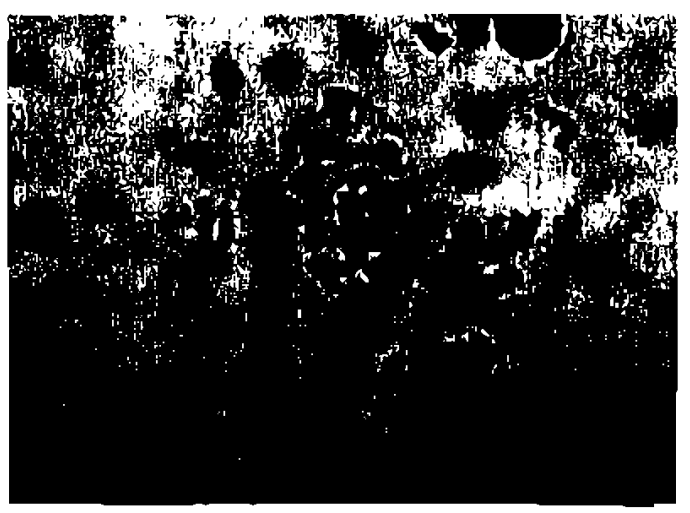

Fig (4): Metaphase chromosomes of mice bone martow cells oflet Lannate trcatment showing ( $a,(b)$ : chromalid break and (c): deletion.

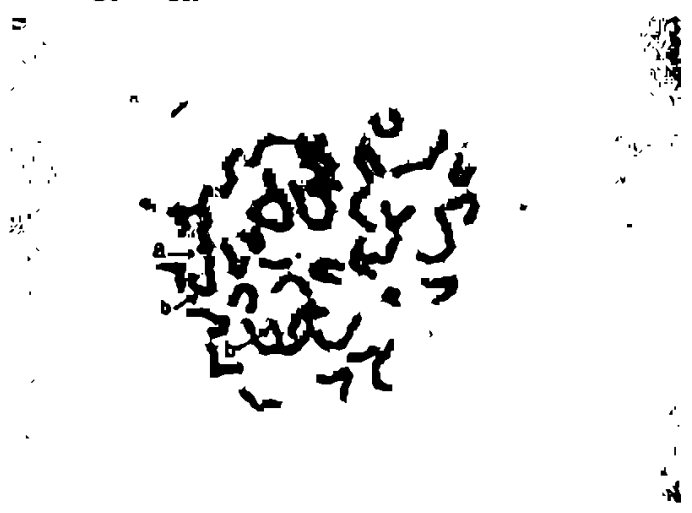

Fig (6): Melaphase chromosomes of mice bone marrow cells after Lannate treatment showing (a): chromosome fragmen! and (b): deletion. 


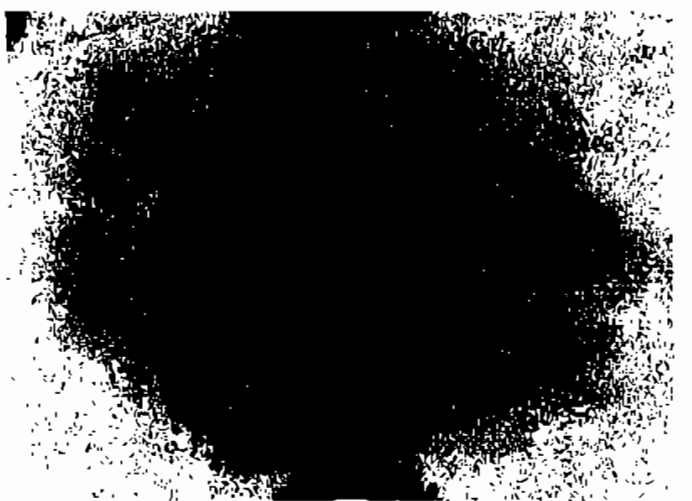

Flg (7): Metaphase chromosomes of mice bone marrow eells after Lannate treatment showing chromosome break.

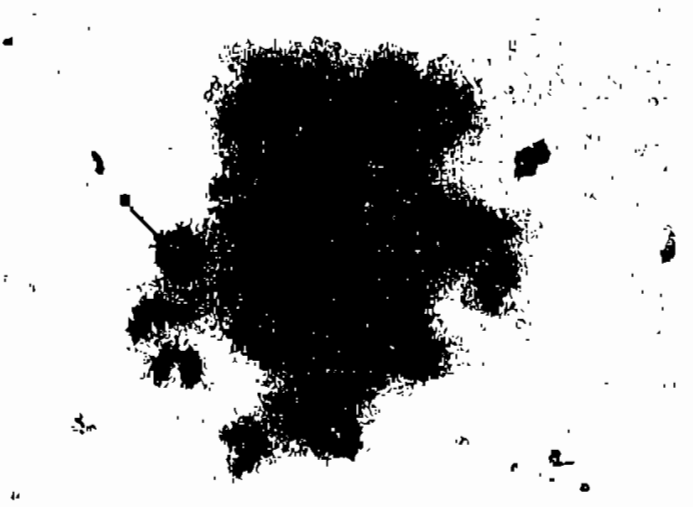

Flg (9): Metaphase chromosomes of mice bone marrow cells after Lannate treatment showing (a): centromeric attenuation and (b): gap.

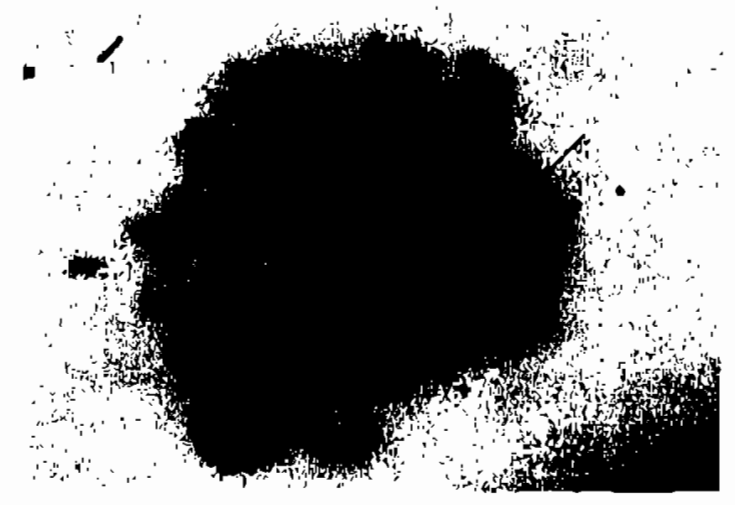

Fig (11): Melaphase chromosomes of mice bone martow cells after Lannate treatment showing ring chromosome.

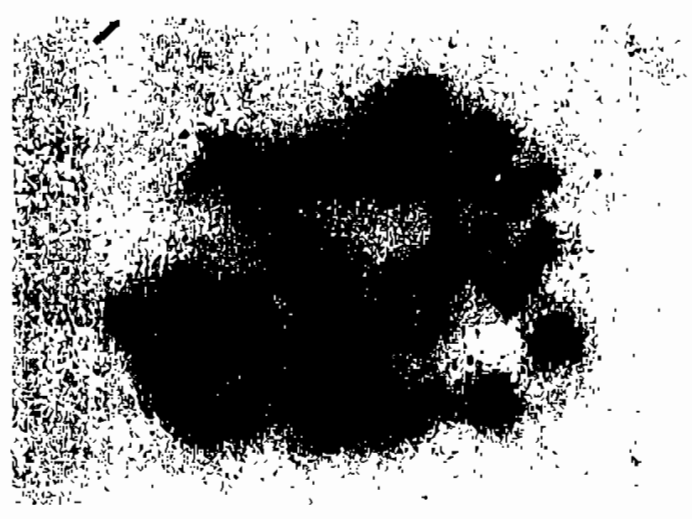

Flg (8): Metaphase chromosomes of mice bone marrow cells after Lannate treament showing centric fusion translocation.

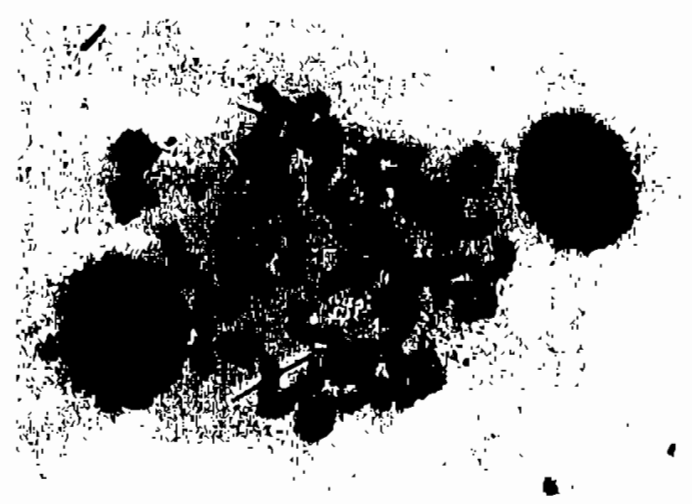

Fig (10): Metaphase chromosomes of mice bone marrow cells after Lannate treatmenl showing stickiness.

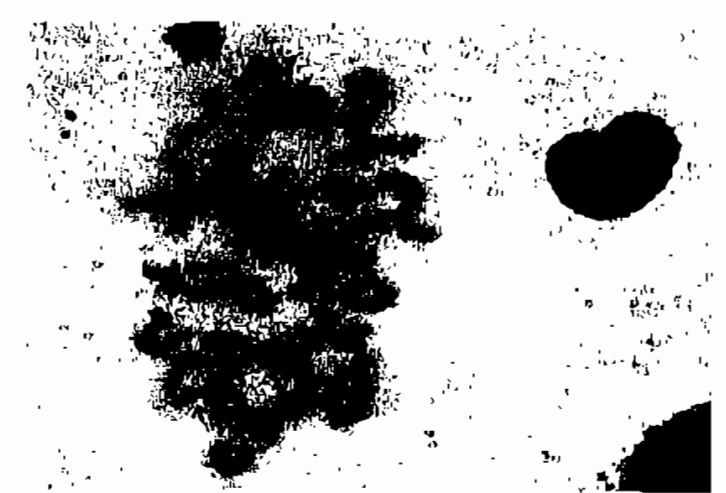

Fig (12): Metaphsse chromosomes of mice bone martow eelis after Lannate treatment showing ehromosome break. 


\section{REFERENCES}

Aboul-Ela, E. 1. (2002) : Cytogenctle studies on Nigella sativa seeds extract and thymoquinonc on mouse cells infected with Schistomlasts using karyotyplng. Mutat. Res. 26. 516. (1-2). 11-17.

Allea, J. W.: Langenbach, R.; Nesnow, S.: Sasseullle, K.; Leavitt, S.; Campbell, J.; Brock, K. and Sharlef, Y. (1882) : Comparative genotoxicity studies of ethyl carbamate: and related chemicals: Further support for vi. nyl carbamate as approxdmate carcinogenic: meLabolite. LIfe sciences \& Mediclne Carcino. genesis, 3. (12), 1437-1441.

Amer, S. M.; Fahmy, M. A. and Donya, B. M. (1896) : Cytogenetic effeel of some insectIcides in mouse spleen. J. Appl. Toxicol.. 16 (1), 1-3.

Asbry, K. M. (1990) : Some toxdrological studies in some carbamates cornmonly used in Egypt. P.V.Sc. Thesis. Faculty or Vet. Med.. Alex. Unlv., Egypt.

Bartol, R.; Banares, F. F.: Navarro, E.: Castellá, E.; Maua, J. and Pastor, C. (2002) : Effect of olive oll on early and late cvents of colon carcinogenesis in rats: modulation of arachidonic and metabolism and local prostaghandin E2 synthesls. Gut. 46, 191 199.

Bleving, R. D.; Lylmeky, W. and Regan, J. D. (1997) : Nitrosated methyl carbamate in secticldes. effect on the DNA of human celis. Mut. Res., 44, 1-7.

Dean Blevins, R.; Mortislee, E. and
Regan. J. D. (1977) : Mutagenicity screening of Dive methyl carbamate Insectjeldes and their nitroso-derivatives using mutants of Salmonella typhimurium LT2. Mut. Res., 56. $1-6$.

De Buyst, B. and Vanlarebeke, N. (1982) : Induction of sister chromatid exchanges in human lymphocytes by aldicarb. thlofanox and methomyl. Mutd. Res. 113. 243-243.

Farre, M.; Fernandaz, M.; Paez, L.; Graaada, L. and Barcel6, D. (2002) : Analysis and toxdcity of methomyl and amelryn after blo degradation. Analytical and Bioanalytical Chemistry, 373, 704-709.

Farrow, M. G.; Cortina T. and Padllla, N. H. (1984) : In vivo bone marrow chromosome study in rats (with) H No. 15.000-Report No. HLo-63-84 from Hazleton laboratories, inc. Submitted to WHO by E.I. Du Pont de Nemours and Co.. Inc., Wilmington, Delaware, USA.

Gir, A. Ttalukder, G. and Bharma, A. (1986) : Slster Chromatid change Induced by metanll Yelllo and nltrate single and combination in vivo on mice. Cancer Lett., 32, 299303.

Hayes, W. J. (1982) : Pesticides studled in man Baltimore, M.D: Willams and Wilkdns.

Hemavathy, r. C. and Kriahnamurthy. N. B. (1987) : Evaluation of Lannate 20. a carbamate pesticlde in the $\mathrm{gcrm}$ cells of male mice. Environ. Res., 42, (2), 362366. 
Keverordes, S.; Gebel, T.; Pav, K; Edenharder R. and Dunkel berg, H. (1996) : Gcnotoxiclty of selccted pesticides in the mouse bone marrow micronucleus test and in the sister chromatid exchange test with human lyrnphocytes in vitro. Toxicology lettcrs. 89. 35-42.

Moutschen-Dahmen, J.; MoutshenDahmen, M. and Degraeve, N. (1984) : Mutagenicity, Carcinogenicity, and Teratogenicity of Insecticides. In: Mutagenicity, Carcinogenicity, and teratogenlcity of industrial pothitants (M.KIrsch-Volders, Ed.). Chap. Plenum press. New York. 127-203.

Pompella, A. (1997) : Blochellistry and histochemistry of oxidative stress and lipid per oxddation int. J. Vit. Nutr. Res.. 67, 289297.

Guintana. R. V.; Arroyo, S. B. G. and Pletrinl, R. V. (1993) : Cytologlcal effects of some carbamate insecticides. I. methomyl and oxamyl in VIcla laba. Rev. Int eontam. Ambient., 9. (2), 65-69.

Rannug, A and Rannug, U. (1984) : Enzyme inhibition as pussible mechanism of the mutagenicity of dithioearbamic acid and dcrvatuves in Salmonella typhimunium chem. Biol. Interac., 49, 329-340.

Soderpalm-Bernde, $C$. and Onflet. A
(1988): The action of carbaryl and Its metabollte alpha- naphthol on milosis in V79 ChInese hamster fbroblasts inductions of the Involvement of somc cholinester in cell division. Mutat. Res., 201. 349-363.

Topakata, M.; RenUzogullarl, E. and Ra. H.B. (1996) : In vivo chromosomal aberration in bone marrow cells of rats with Marshal. Mutat. Res.. 371. 259-264.

Wang. T. C.; Chou, C. M. and Cbang. Y. L. (1998) : Genetlc toxdcity of N-methyl carbomate insecticides, and their $\mathrm{N}$-nitroso derivatves. Mutagenesis. 13, (4), 405-408.

Waters, M. D.; Sandhu, S. S.; Simmon V. F.; Mortelmans, K. E.; Mitchell, A. D.; Forgeneon, T. A; Jones, D. C. L. and Valencla R. and Garrette, N. E. (1982) : Study of pesticide genotoxdclty. In Fleek. R.A and Hollaender, A. Ed. Genetle toxlcology: in agricultural perspectve. New York. London. Plenum press, 275-324.

WHO, (1986) : Carbamate pesticldes: A General introduction. Environ Health Crilera. 64.

Wojclechowak1, J. P.; Kaur, P. and Gabbarwal, P. S. (1952) : Introduction of ouabain resistanee in V-79 eells by four carbamates pesticldes. Envion Res. 29. (1). 48-53. 


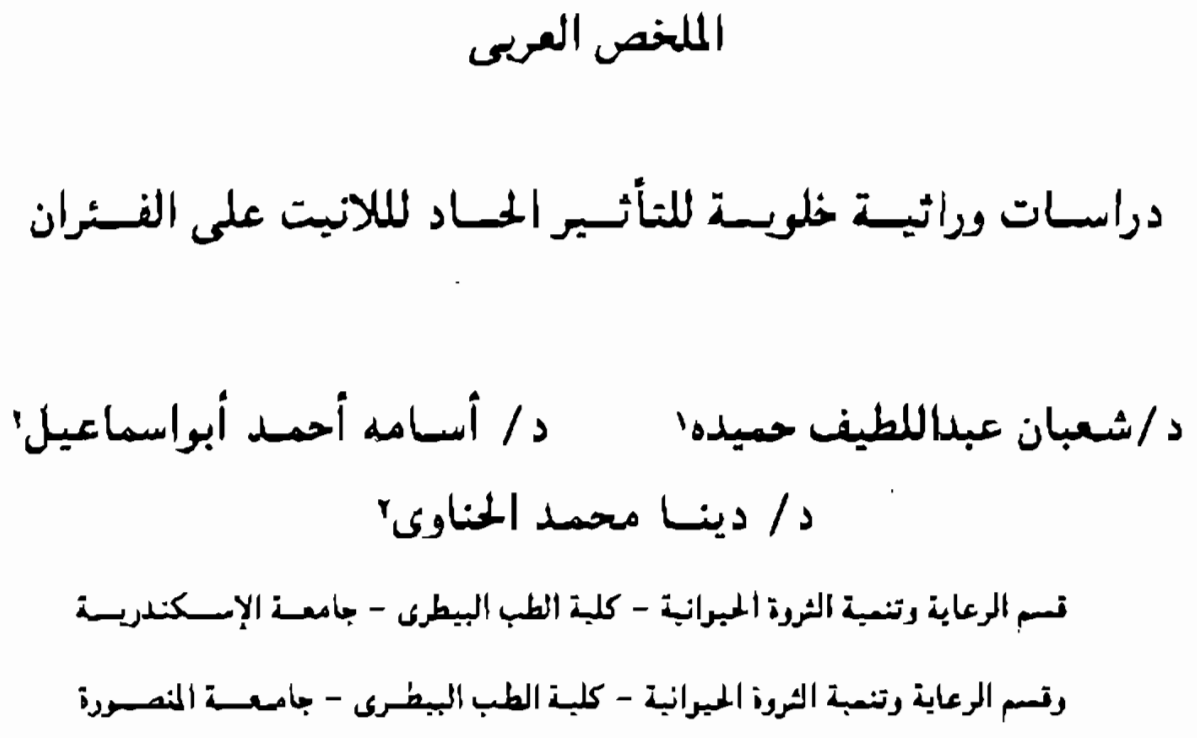

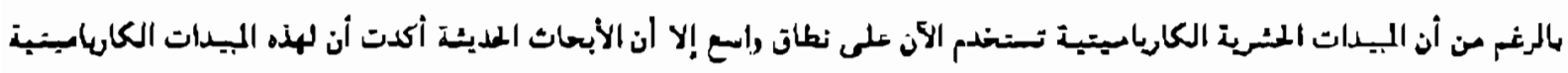

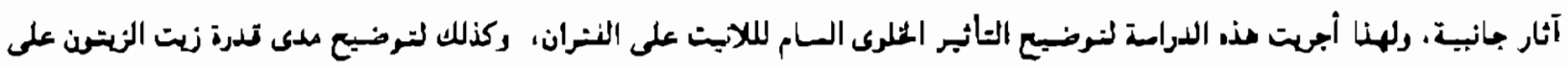

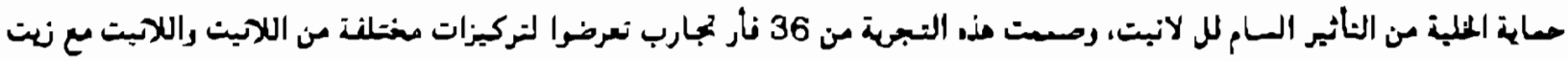

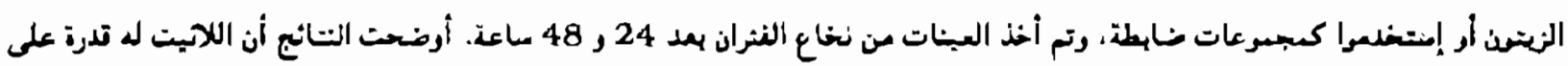

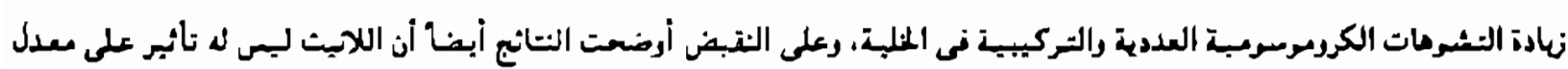

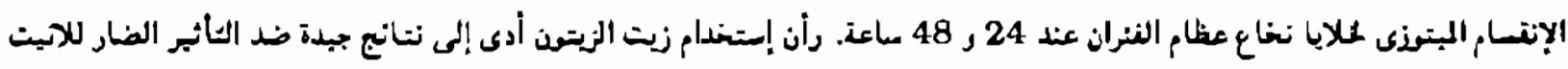

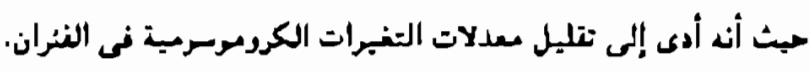

